\title{
Electromagnetic Fields in Dental Clinics
}

\author{
Mehmet Güven ${ }^{1}$, Erdal Eroğlu ${ }^{1 *}$ and Selçuk Çömlekçi ${ }^{2}$ \\ ${ }^{1}$ Department of Prosthodontics, Süleyman Demirel University, Turkey \\ ${ }^{2}$ Department of Telecommunication, Süleyman Demirel University, Turkey
}

*Corresponding author: Erdal Eroğlu, Department of Prosthodontics, Süleyman Demirel University, Faculty of Dentistry, Turkey

To Cite This Article: Mehmet Güven, Erdal Eroğlu, Selçuk Çömlekçi. Electromagnetic Fields in Dental Clinics. Am J Biomed Sci \& Res. 2021 13(5). AJBSR.MS.ID.001902. DOI: 10.34297/AJBSR.2021.13.001902.

Received: 眥 July 07, 2021; Published: 酮 July 26, 2021

\begin{abstract}
Abbreviations: EMF: Electromagnetic Field; WHO: World Health Organization; ICNIRP: The International Commission on Non-Ionizing Radiation Protection; IEEE: Electrical and Electronics Engineers
\end{abstract}

\section{Introduction}

The human body has been exposed to the electromagnetic field (EMF) for thousands of years. The most significant causes of this exposure are natural resources such as the sun, earth's core, and lightning. However, with the technology and power tools that we have developed in the last century, the EMF has entered our lives at a rate far higher than we can imagine. These devices may seem safe and harmless, but they have some effects and interactions that we cannot see through the human eye or fully perceive with our other senses. The EMF emitted by these tools has become undeniable and indispensable parts of our lives. Organizations such as the World Health Organization (WHO), The International Commission on Non-Ionizing Radiation Protection (ICNIRP), and the Institute of Electrical and Electronics Engineers (IEEE) have been making arrangements and studies for years about electrical appliances and EMFs. These institutions provide limitations and recommendations about devices that may impact human life and use these devices. The EMF is defined by WHO as follows; When an outlet-mounted device is turned on, an electric current pass through it and creates an electromagnetic field in proportion to the power of the given electric supply. The magnetic field is very close to the electrical device, and it weakens as it moves away from the device. It is not clear how the mechanism of action of electromagnetic fields works. Today, it is known that the proteins in the cell and the free membrane are overly sensitive to EMF. EMF alters the chemical composition of the cell, alters its metabolic activity and response to stimuli. Most of these effects are not acute but the result of the prolonged presentation [1].

Most of the functions in the human body are performed by electrical and chemical activities at the cell level. These activities are mostly carried out by transferring positive or negatively charged ions into or out of the cell. The EMF formed around us will affect this exchange, which arises from the awareness of electrical potential. Especially with the effect of the permeability of the cell membrane at certain frequencies, the transition of some ions that need to remain out of the cell into the cell will be facilitated, or the escape of the ions that should remain in the cell will be easier to escape out of the cell, due to these transfer disorders, the potential difference between intracellular and extracellular cells will become inoperable $[2,3]$. This deterioration in cell level can cause many different symptoms or disorders depending on which part of the body is affected. It is difficult to monitor and understand the effects on health regularly, but an early or definitive diagnosis can be made with predictable complaints [4]. A study described dizziness, nausea, blood pressure, and change in pulse, arrhythmia, and impaired hand-eye coordination as the most common effects of EMF exposure [5]. In dental clinical practice, many electrically driven devices are used in the daily routine. The most used devices are aerators, micromotors, laboratory-type micromotors, contra-angle 
handpieces, straight handpieces, cavitrons, light polymerization devices, reflectors and ultrasonic cleaners. However, there are no descriptive regulations or studies on the possible side effects of these devices concerning daily clinical practice [6].

Dentists' occupational diseases include carpal tunnel syndrome, spine and back pain, head and neck pains, joint disorders, vision and hearing problems, and vibration syndrome. The main etiological cause of these diseases is generally related to recurrent posture disorders and vibration of rotary hand tools $[7,8]$. However, the EMFinduced effects of electrical devices used in a clinical environment are often ignored. Lately, it has been observed that these electrical dental devices can create more than three times the EMF of $1 \mu \mathrm{T}$ (microtesla), the EMF recommended by IEEE during use (Table 1) [9]. The effects of EMF on humans are usually due to prolonged exposure. However, the exposure duration varies for each individual and does not always cause the same ailments $[10,11]$. As mentioned above, these instruments are used simultaneously in daily clinical dental practice. Thus, the emitted EMF by each device unites and increases the total intensity. Although the patient's time at the dental unit is limited to minutes, the dentist and related dental staff working in the same environment can be exposed to this EMF for hours on a routine working day. Although the effects of the EMF are not generally seen as acute, it is also known that they accumulate over time and manifest themselves. The data shows that dentists and healthcare personnel may also interact above acceptable limits due to the increasing use of EMF and electromagnetic radiation (EMR)-emitting devices in the healthcare sector. Research in these environments is needed for preventing possible occupational diseases.

Table 1: Electrical and magnetic fields of some devices used in dental treatment [9].

\begin{tabular}{|c|c|c|c|c|c|}
\hline & & $\begin{array}{c}\text { Stand by Position (In } \\
\text { Contact) }\end{array}$ & $\begin{array}{l}\text { While Running (In } \\
\text { Contact) }\end{array}$ & $\begin{array}{l}10 \mathrm{~cm} \text { distance while } \\
\text { running }\end{array}$ & $\begin{array}{c}30 \mathrm{~cm} \text { distance while } \\
\text { Running }\end{array}$ \\
\hline & & Avg $\pm D V$ & Avg $\pm D V$ & Avg $\pm D V$ & Avg $\pm D V$ \\
\hline \multirow[t]{2}{*}{$\begin{array}{c}\text { Contra angle } \\
\text { handpiece (Red belt) }\end{array}$} & Electric field $(\mathrm{V} / \mathrm{m})$ & $0.884 \pm 0.077$ & $0.62 \pm 0.051$ & $0.504 \pm 0.095$ & $0.378 \pm 0.037$ \\
\hline & Magnetic field (uT) & $0.01 \pm 0$ & $5.24 \pm 0.054^{*}$ & $3.62 \pm 0.077^{*}$ & $1.96 \pm 0.089 *$ \\
\hline \multirow[t]{2}{*}{$\begin{array}{c}\text { Contra angle } \\
\text { handpiece (Blue belt) }\end{array}$} & Electric field $(\mathrm{V} / \mathrm{m})$ & $0.896 \pm 0.063$ & $1,582 \pm 0,046$ & $0.916 \pm 0.076$ & $0.485 \pm 0.054$ \\
\hline & Magnetic field (uT) & $0.12 \pm 0.044$ & $17.66 \pm 0.162^{*}$ & $6,066 \pm 0,076^{*}$ & $3.45 \pm 0.054^{*}$ \\
\hline \multirow[t]{2}{*}{ Endodontic handpiece } & Electric field $(\mathrm{V} / \mathrm{m})$ & $0.038 \pm 0.019$ & $0.358 \pm 0.046$ & $0.18 \pm 0.027$ & $0.162 \pm 0.023$ \\
\hline & Magnetic field (uT) & $0.1 \pm 0.173$ & $19.06 \pm 0.167 *$ & $1.31 \pm 0.060^{*}$ & $0.386 \pm 0.020$ \\
\hline
\end{tabular}

Note: Values that exceed the dangerous limit for human health are marked as*

\section{References}

1. World Health Organization (2007) Extremely low-frequency fields. World Health Organization.

2. Panagopoulos DJ, Karabarbounis A, Margaritis LH (2002) Mechanism for action of electromagnetic fields on cells. Biochemical and biophysical research communications 298(1): 95-102.

3. Shckorbatov Y (2014) The main approaches of studying the mechanisms of action of artificial electromagnetic fields on cell. Journal of Electrical \& Electronics 3(2):1

4. Cohen R, Horie S (2007) Injuries caused by physical hazards. Current occupational and environmental medicine. (4 $4^{\text {th }}$ Edn) McGraw-Hill Companies. New York 122-50.

5. Franco G, Perduri R, Murolo A (2008) Health effects of occupational exposure to static magnetic fields used in magnetic resonance imaging: a review. La Medicina del lavoro 99(1): 16-28.

6. Kameda T, Ohkuma K (2014) Electromagnetic fields from dental devices and their effects on human health. Journal of Electrical \& Electronics 3(1): 1 .
7. Şenel B (2007). Hazardous diseases for dentists and dentist's occupational illnesses. Gülhane Tıp Dergisi 49(3): 204-212.

8. Soylu M, Altındiş S (2018) Effect of dentist working conditions on occupational musculoskeletal system diseases. SDU Journal of Health Science Institute/SDÜ Saglik Bilimleri Enstitüsü Dergisi 9(1).

9. Eroğlu E, Erken M, Geçin M, Demirekin Z, Çömlekçi S (2019) Electromagnetic field in public oral and dental health centers; Isparta, Turkey; Isparta, Türkiye. SDU Journal of Health Science Institute/ Süleyman Demirel Üniversitesi Sağlık Bilimleri Dergisi 10(2): 129-136.

10. Belyaev I, Dean A, Eger H, Hubmann G, Jandrisovits R, et al. (2016) Europaem Emf Guideline 2016 for the prevention, diagnosis and treatment of EMF-related health problems and illnesses. Reviews on environmental health 31(3): 363-397.

11. Ilhan M, Erkan V, Çol M (2017) Electromagnetic field mapping and health status of workers exposed to electromagnetic fields in a university hospital. Sağlık ve Sosyal Politikalara Bakış 1(1): 51-58. 